\title{
SIASAT-SIASAT NATURALISME DALAM FILSAFAT HUKUM: SEBUAH KONTRIBUSI FILSAFAT ILMU
}

\author{
Tanius Sebastian \\ email: sebastian_tanius@yahoo.com
}

\begin{abstract}
Naturalism is one of the main topics that explore the philosophical discourse. This article intends to discuss the philosophical problems of naturalism in jurisprudence. The argumentations of naturalism have affected the configuration of methodological debate in jurisprudence; between the descriptive approach and the evaluative approach. By reviewing the project of naturalism in metaphysics and epistemology and then scrutinizing how the ideas of naturalism work in jurisprudence, this article will exhibit a contribution of the philosophy of science to the scientific reflection of law. The development of naturalism creates challenges and chances at once for methodological tracing in the philosophy of law.
\end{abstract}

Keywords:

Naturalism, Methodological Debate, Jurisprudence, Philosophy of Science, Science

\begin{abstract}
Abstrak
Naturalisme adalah salah satu topik utama yang menjelajahi pembicaraan filsafat. Artikel ini bermaksud untuk mendiskusikan problem filosofis naturalisme dalam filsafat hukum. Argumentasi-argumentasi naturalisme telah mempengaruhi konfigurasi perdebatan metodologis dalam filsafat hukum; antara pendekatan deskriptif dan pendekatan evaluatif. Dengan cara meninjau ulang proyek naturalisme dalam metafisika dan epistemologi dan kemudian memeriksa bagaimana gagasan-gagasan naturalisme bekerja dalam filsafat hukum, artikel ini akan memperlihatkan sebuah kontribusi filsafat ilmu untuk refleksi keilmuan hukum. Pengembangan naturalisme menciptakan tantangan sekaligus peluang bagi penelusuran metodologi filsafat hukum.
\end{abstract}

Kata kunci

Naturalisme, Perdebatan Metodologis, Filsafat Hukum, Filsafat Ilmu, Ilmu Pengetahuan

\section{Pendahuluan}

Naturalisme merupakan salah satu topik yang menjelajahi pembicaraan filsafat. Geire bahkan menyatakan bahwa naturalisme adalah program umum bagi semua jenis filsafat, termasuk etika, filsafat bahasa dan filsafat pikiran, epistemologi, serta filsafat ilmu. ${ }^{1}$ Maka bisa dibayangkan betapa luasnya cakupan wilayah gagasan dan problematisasi dari naturalisme. Di lain pihak, filsafat ilmu tampil untuk merefleksikan pelbagai pendasaran ilmu pengetahuan, fitur-fitur

\footnotetext{
1 Ronald N. Geire, "Naturalism" dalam The Routledge Companion to Philosophy of Science, eds. Stathis Psillos and Martin Curd, 213 (Routledge, London and New York, 2008).
} 
teknisnya, serta sejumlah aspek di sekitarnya seperti pola perilaku (manusiawi) para ilmuwan, sampai pencapaian yang dihasilkannya. Tentu dalam hal yang disebut terakhir ini implisit pula masalah dampak dan konsekuensi etis, baik yang ke dalam (berupa: corak ilmu pengetahuan, komunitas ilmiah, dan sikap individu ilmuwan) maupun yang ke luar (berupa: institusi masyarakat dan lingkungan hidup).

Kendati demikian, sekian taraf pengertian tentang naturalisme dan filsafat ilmu itu tak mesti merepotkan kita seperti ungkapan yang mempertanyakan asalusul ayam dan telur, mana yang terlebih dahulu: naturalisme atau filsafat ilmu? ${ }^{2}$ Tanpa ada pretensi sebelumnya untuk membela pandangan Geire tadi, tinjauan artikel ini didorong oleh ketertarikan atas keterkaitan antara doktrin naturalisme yang berkembang di dalam pendekatan filsafat ilmu dan ranah-ranah filosofis lain khususnya epistemologi dan metafisika. Dengan kekayaan khazanah tersebut pun artikel ini tak dimaksudkan untuk menerangkan problem filosofis naturalisme yang ada secara utuh menyeluruh sehingga diskusi akan dibatasi pada sebuah disiplin keilmuan tertentu, yakni filsafat hukum (jurisprudence). ${ }^{3}$ Pengertian

2 Pendekatan sejarah filsafat mungkin bisa membantu menjelaskan ihwal ini. Dari perspektif historis filsafat Barat abad ke-20, doktrin naturalisme dapat kita temukan sumber inspirasinya dari kritik Willard Van Orman Quine (1908-2000) terhadap gagasan filsafat analitik. Dengan begitu, doktrin tersebut berada di bawah suatu tema besar yang meliputi perkembangan tradisi analitik kemudian, yakni tema filsafat Kantian. Kajian filsafat ilmu, yang sejauh dimengerti sebagai refleksi atas ciri dan cara kerja ilmu, terlibat juga di bawah tema besar tersebut. Hal ini tampak dari konsep "naturalisme ilmiah" (scientific naturalism) yang didasarkan pada pemikiran Wilfird Sellars serta Quine sendiri. Saya mengikuti penjajakan sejarah filsafat ini dari: Robert Hanna, "Kant in the Twentieth Century" dalam The Routledge Companion to Twentieth Century Philosophy, ed. Dermot Moran, 176-183 (Routledge, London and New York, 2008).

3 Menurut pandangan sistematik yang merefleksikan ilmu hukum berdasarkan struktur disiplin keilmuan, filsafat hukum merupakan disiplin hukum yang berada di atas teori hukum dan ilmu hukum. Berdasarkan kerangka filsafat ilmu van Peursenian dan gagasan ilmu hukum dari Paul Scholten, ilmu hukum (praktis) dipandang secara prismatik sebagai domain di bawah teori hukum. Menurut cara pandang tersebut, filsafat hukum merupakan disiplin reflektif-kritis tertinggi atas hukum. Sebuah penelitian yang mempersembahkan pandangan seperti ini adalah: B. Arief Sidharta, Refleksi tentang Struktur Ilmu Hukum: Sebuah Penelitian tentang Fundasi Kefilsafatan dan Sifat Keilmuan Ilmu Hukum sebagai Landasan Pengembangan Ilmu Hukum Indonesia (CV. Mandar Maju, Bandung, 2009). Pada tulisan ini, saya mengikuti tradisi filsafat hukum Anglo-Amerika yang memakai istilah "jurisprudence". Arief Sidharta di dalam bukunya tersebut mengartikan jurisprudence sebagai teori (ilmu) hukum, sedangkan saya memandangnya sebagai pemikiran reflektif tentang apa itu hukum (as it is) dan bagaimana hukum itu seharusnya (as ought to be). 
filsafat hukum di sini adalah penyelidikan filosofis yang tak terbatas pada kasus partikular atau yurisdiksi tertentu atas kodrat atau hakikat (nature) dari hukum. ${ }^{4}$

Dalam diskursus filsafat hukum, problem metodologi ilmiah melahirkan perdebatan sengit seputar konsep hukum di wilayah kajian yang bernama filsafat hukum analitis (analytic jurisprudence). Dalam rangka perdebatan inilah kita dapat melihat adanya peran sentral naturalisme, yaitu ketika gagasan Quine, yang menyerang pembedaan makna kebenaran analitis/sintesis, mampu mendobrak 'corak esensial hukum' yang secara metodologis berlandaskan pada pembedaan tadi. ${ }^{5}$ Sampai di sini kita bisa melihat bagaimana doktrin naturalisme menghadirkan tantangan sekaligus peluang yang menarik untuk dibahas. Bagi filsafat ilmu, tantangan sekaligus peluangnya adalah epistemologi ternaturalisasi, sedangkan bagi filsafat hukum, naturalisme metodologis menghasilkan implikasi yang tak main-main baik secara teoritis maupun praktis. Oleh sebab itu, idea artikel ini akan berkisar pada pembicaraan tentang doktrin naturalisme terutama yang berasal dari Quine serta perdebatan filsafat hukum sejauh yang berhubungan dengan doktrin Quine tersebut. Tokoh yang dibahas berkenaan dengan topik yang disebut belakangan ini adalah Brian Leiter. Pembacaannya atas doktrin naturalisme Quine secara tajam melembagakan naturalisme dalam filsafat hukum umumnya dan dalam kerangka metodologi filsafat hukum khususnya.

Sekali lagi ingin ditekankan bahwa diskusi yang ditujukan terhadap filsafat hukum di sini bertolak dari perspektif filsafat ilmu. Apabila filsafat ilmu kita pahami bersama sebagai sebuah refleksi atas ciri dan cara kerja ilmu, maka selayaknyalah refleksi tersebut berkecimpung lebih ke dalam, yaitu masuk ke medan disiplin "ilmu" itu sendiri. Naturalisme, seperti yang telah ditunjukkan, ibarat proyek yang menjajal setiap anggapan filosofis dengan menyusupi pelbagai bidang filsafat sistematis. Perdebatan dalam filsafat hukum mengenai soal

4 "General jurisprudence, as this philosophical inquiry about the nature of law is called, is meant to be universal". Andrei Marmor, The Nature of Law, http://plato.stanford.edu/entries/ lawphilnature/ (terakhir diakses 19 Maret 2015).

5 Dennis Patterson, "Notes on the Methodology Debate in Contemporary Jurisprudence: Why Sociologist Might Be Interested", http://papers.ssrn.com/sol3/papers.cfm? abstract_id=848984 (terakhir diakses 3 Januari 2014). 
metodologi rupanya didalangi pula oleh siasat proyek naturalisme. Pertanyaan pokoknya adalah: apa saja dan bagaimana siasat-siasat naturalisme yang dijalankan pada ranah perdebatan filsafat hukum? Apa implikasi dari bekerjanya siasat tersebut bagi refleksi atas ilmu, khususnya di bidang filsafat hukum? Maka ada baiknya untuk memahami doktrin naturalisme dalam rangka mencerahkan refleksi keilmuan filsafat hukum. Titik persinggungan semuanya itu tak lain adalah ranah filsafat ilmu. Dari situlah kita akan memulai penggarapan proyek.

\section{Proyek Naturalisme dalam Filsafat Ilmu}

Naturalisme dapat digambarkan sebagai sebuah proyek yang melibatkan pembicaraan epistemologis, metafisik, serta pelbagai topik seputar filsafat ilmu. Kita akan melihat pokok-pokok pemikiran dari proyek naturalisme tersebut khususnya yang berhubungan dengan epistemologi, metafisika, dan sejumlah topik filsafat ilmu. Tinjauan ini kiranya berguna untuk menggambarkan peta besar yang menjadi petunjuk latar belakang pergulatan dalam proyek naturalisme, terutama yang akan dialami dalam perdebatan filsafat hukum. Oleh karena itu, bagian ini akan didekasikan untuk mengurai gagasan yang terkait dengan tiga ranah filosofis tersebut, lalu mengidentifikasi masalah di sekitar proyek naturalisme serta keutamaan yang dimilikinya. Naturalisme punya andil yang penting bahkan menjanjikan bagi perkembangan ide filsafat ilmu dan ilmu pengetahuan sendiri yang antara lain berupa reliabilitas ilmu, justifikasi teori, penentuan metode ilmiah, serta cara pandang terhadap realitas. Hal-hal tersebut dapat ditemukan khususnya dalam ulasan yang menyangkut relasi filsafat ilmu dengan metafisika dan epistemologi.

Kita mulai dari metafisika. Visi naturalisme mengemuka dari kerangka hubungan metafisika dan filsafat ilmu. Seiring perjalanan sejarah pemikiran, hubungan tersebut berlangsung tidak akur. Metafisika dan filsafat ilmu berupaya untuk saling menyangkal keberadaan pasangannya, metafisika menetapkan dirinya sebagai telaah a priori atas segala esensi entitas baik yang aktual maupun yang mungkin, sedangkan filsafat ilmu yang banyak diperkutatkan dengan pola 
kerja ilmiah hanya menyediakan tempat bagi investigasi logis yang empiris. Kondisi hubungan seperti ini digambarkan Callender sebagai sebuah benturan dan dilatarbelakangi oleh kritik Kant yang menganggap metafisika itu semacam 'perusakan' pemahaman. ${ }^{6}$ Para penganut aliran positivisme logis yang mewarisi anggapan Kant ini memperpanjang serangan terhadap metafisika, sampai akhirnya Quine menyanggah balik pernyataan Carnap bahwa metafisika dalam bentuk pertanyaan ontologis hanyalah urusan praktis bagaimana menjelaskan struktur teoritis (framework) yang ini dan bukannya yang itu yang dipakai. Sanggahan Quine tentang adanya pemisahan makna kebenaran yang analitik dengan yang sintetik mendobrak idea 'analisis konseptual'. Jika gagasan Quine ini ada benarnya, maka tidak berlaku lagi pemisahan tegas kebenaran konseptual/linguistik yang analitik dengan kebenaran faktual/kontingen yang sintetik. ${ }^{7}$

Meskipun diwarnai oleh pelbagai gagasan yang berkembang lebih lanjut, kondisi relasi metafisika dan filsafat ilmu pada kasus serangan Quine terhadap positivisme mulai memperlihatkan corak naturalisme. ${ }^{8}$ Mengikuti Callender, dari tindakan "menyelamatkan" metafisika (kendati tetap tidak menyediakan pendasaran rasional untuk terlibat dengan metafisika) ternyata selanjutnya Quine malah menumbuhkan sikap curiga terhadapnya. Bagi Callender, hal tersebut dapat

6 Craig Callender, "Philosophy of Science and Metaphysics" dalam The Continuum Companion to the Philosophy of Science, eds. Steven French and Juha Saatsi, 34 (Continuum, London, New York, 2011).

7 Id. hlm. 35.

8 Seperti yang ditampilkan oleh Callender, seiring perkembangan pemikiran terdapat ragam perspektif yang mencoba memahami proses keterjalinan metafisika dengan filsafat ilmu. Selain Quine sendiri, pandangan lain yang menonjol adalah dari Saul Kripke yang juga memiliki keberatan atas konsepsi 'pluralisme kerangka' (framework pluralism) Carnap yang berujung menjadi pragmatisme. Callender mengibaratkan Quine sebagai seseorang yang menyiapkan ruang bagi metafisika dan Kripke-lah yang merapihkannya. Hal itu Kripke lakukan dengan menggagas bahwa intuisi punya kapasitas bagi apa yang mungkin sehingga dari situ terdapat modalitas yang tidak pasti dapat direduksi menjadi modalitas yang logis atau ilmiah, alias 'modalitas metafisis'. Maka Kripke pun didaulat menemukan adanya kebutuhan-kebutuhan akan yang a posteriori. Lantas masih terdapat pula pelbagai perspektif lain yang melontarkan konsepsi-konsepsi mengenai relasi metafisika dan filsafat ilmu, antara lain seperti 'Filsafat Kedua' dari P. Maddy yang merespon gagasan ketiadaan 'filsafat pertama' dari Quine dengan melihat adanya kesinambungan dari dimensi ontologis pada persepsi ke proses ilmiah. Id. 35-36. 
disaksikan dari pertumbuhan naturalisme terutama yang terwujud dalam filsafat ilmu ternaturalisasi dan epistemologi ternaturalisasi. ${ }^{9}$ Dari sinilah muncul gagasan terkemuka Quine mengenai tidak adanya "filsafat pertama" sebagai justifikasi filosofis atas apa yang ilmu pengetahuan hasilkan. Doktrin naturalisme ini berimplikasi serius tatkala diboyong ke dalam perdebatan filsafat hukum.

Kisah hubungan filsafat ilmu berlangsung pula dengan epistemologi. Dalam langkah-langkah sistematiknya ketika memeriksa hubungan antara filsafat ilmu dan epistemologi, Bird mengemukakan adanya pasangan karakter masing-masing dari hasil hubungan keduanya itu. ${ }^{10}$ Dari perspektif filsafat ilmu, terwujud dua pasang karakter berupa tendensi yang saling berlawanan, yakni tendensi partikularis dan generalis, sedangkan dari sisi epistemologi lahir epistemologi internalis dan eksternalis. Yang menjadi titik tolak karakterisasi ini adalah pertanyaan tentang bagaimana hubungan peran ilmu dengan produksi pengetahuan. Garis besar jawaban dari masing-masing pasangan karakter tersebut adalah seperti berikut ini. Tendensi partikularis menampilkan adanya tekanan filsafat ilmu terhadap hakikat ilmu dalam aktualitas praktiknya. Filsafat ilmu dimengerti sebagai telaah atas pengelolaan ilmu yang didasarkan pada proses penalaran beserta episode sejarah pembentukannya. Seperti yang diterangkan oleh Bird, sejak Whewell sampai Kuhn dan perdebatan tentang perkembangan ilmu bersama Popper dan Lakatos, pandangan partikularis menggalakkan fakta historis sebagai kunci perkembangan paradigma ilmiah, metode justifikasi, dan paham epistemologi dari ilmu. Sementara itu, tendensi generalis (yang kentara pada empirisisme logis dan telah dimulai oleh John Stuart Mill) menganggap adanya hubungan yang kontinu antara pemahaman atas pengetahuan sehari-hari dan pembentukan pengetahuan ilmiah. Yang menjadi tolok ukur dan batasan dalam menghasilkan suatu kesimpulan ialah pengalaman

\footnotetext{
9 Id. hml. 36.

10 Bagian yang menyangkut filsafat ilmu dan epistemologi mengikuti uraian Bird dalam teks: Alexander Bird, "Philosophy of Science and Epistemology" dalam The Continuum Companion to the Philosophy of Science, eds. Steven French and Juha Saatsi, (Continuum, London and New York, 2011).
} 
sensorik individual. Dalam tendensi generalis, ilmu pengetahuan mencerminkan fondasi epistemologis dari pemikiran sehari-hari sehingga ilmu pengetahuan itu lebih murni, meskipun secara esensial sama, dengan pemikiran sehari-hari. ${ }^{11}$

Epistemologi internalis dan eksternalis dijelaskan oleh Bird juga sebagai pasangan karakter yang saling berlawanan. Menurut pihak internalis, penggunaan suatu metode dalam rangka memperoleh pengetahuan atau keyakinan yang terjustifikasi, menuntut subjek pelakunya untuk punya landas rasional atas keyakinannya bahwa langkah metode tersebut punya kemungkinan untuk mencapai kebenaran. ${ }^{12}$ Pihak eksternalis menyangkal pendapat internalis ini beserta sikap internalis yang lebih mengedepankan justifikasi epistemik hasil kondisi intrinsik subjek daripada faktor-faktor di luar diri subjek. Dalam rangka mencapai kebenaran, internalisme bersifat a priori dan mendasarkan diri pada kemampuan refleksi internal subjek. Sebaliknya, eksternalisme menyadari adanya kondisi empiris yang mempengaruhi keyakinan subjek dalam membuat justifikasi dan yang bahkan mungkin tidak disadari oleh si subjek. ${ }^{13}$ Retakan antara internalisme dan eksternalisme epistemologi diperagakan dengan bagus dalam dua disposisi kontemporer yang kontras tentang metode ilmiah: epistemologi Bayesian yang percaya hanya pada adanya satu metode ilmiah bagi semua ilmu dan "Kesimpulan untuk Eksplanasi Terbaik" (Inference to the Best Explanation) yang melihat adanya keragaman metode. ${ }^{14}$

11 "Because science and everyday thinking are essentially the same, except that science is purer, and understanding of their common epistemological foundation is best gained by looking at science. Thus, for the positivists, epistemology is philosophy of science." Id. hlm. 17.

12 Id. hlm. 23.

13 Bird mengetengahkan bahwa konsepsi internalisme dan eksternalisme ini mengandung kesulitannya masing-masing sehingga memberi kesempatan kepada yang satu untuk berkontribusi bagi yang lain. Contohnya saja mengenai reliabilisme yang berkembang dari eksternalisme. Reliabilisme menyatakan bahwa reliabilitas suatu metode bisa saja tak diketahui atau disadari ketika seseorang telah memiliki justifikasi atas keyakinannya akan suatu pengetahuan. Seperti yang ditunjukkan oleh Bird, bentuk eksternalisme seperti ini mengalami kesulitan dalam hal kinerja ilmu. Pada derajat tertentu, pada ilmu dibutuhkan kesadaran reflektif akan kekuatan justifikasi keyakinan melalui bukti dan argumen sehingga internalisme yang melandasi langkah-langkah ilmiah dalam proses produksi keyakinan pun ada benarnya. Id. 24 .

14 Id. hlm. 19-22. 
Sangat penting untuk menggarisbawahi bahwa kontras epistemologi Bayesian dengan 'Kesimpulan untuk Eksplanasi Terbaik' yang menjadi contoh perbedaan epistemologi internalis dan eksternalis merupakan representasi dari tegangan tendensi generalis dan partikularis. Tetapi tegangan ini terjadi justru di dalam tendensi partikularis menurut perspektif filsafat ilmu sendiri, yakni tendensi yang tidak melihat adanya kontinuitas penalaran ilmiah dengan pemikiran biasa sehari-hari. ${ }^{15}$ Tendensi partikularis ini yang terkandung dalam epistemologi eksternalis lantas termanifestasikan menjadi epistemologi ternaturalisasi. Seperti yang akan kita bahas nanti, epistemologi ternaturalisasi ini menawarkan penyelesaian bagi kontroversi hasil hubungan filsafat ilmu dan epistemologi dengan sejumlah pertimbangan yang cukup menjanjikan mengenai kapasitas pengetahuan subjek, kinerja metode ilmiah, justifikasi cara pandang, standar penjelas, hasil penjelasan yang terbaik, dan pembuktiannya berdasarkan investigasi empiris, historis, serta psikologis. Dengan lain perkataan, gagasan epistemologi ternaturalisasi punya argumentasi yang kuat dalam menjelaskan kesuksesan sebuah teori yang makin berkorelasi dengan kebenaran dan dalam melandasi reliabilitas ilmu secara epistemologis.

Setelah mengamati kehadiran naturalisme dari hasil hubungan filsafat ilmu dengan metafisika dan epistemologi, proyek umum naturalisme kemudian berlanjut dengan menyasar pelbagai topik di sekitar filsafat ilmu sendiri. Geire memaparkan bagaimana naturalisme menyasar proses keilmuan termasuk metode mensertifikasi klaim pengetahuan tertentu. ${ }^{16}$ Dengan nada pembelaan, Geire memandang bahwa pengkarakteran positif atas naturalisme, sebagai paham yang teguh memahami segala aspek di dunia ini secara natural, terbebani oleh godaan untuk menyertakan argumentasi a priori. ${ }^{17}$ Godaan tersebut muncul sebab kita dapat mempertanyakan, bagaimana bisa tiap orang tahu bahwa setiap aspek

\footnotetext{
15 Id. hlm. 19.

16 Ronald N. Geire, supra catatan no. 2, pada 215.

17 "Naturalist insists that all aspects of the world can be accounted for naturalistically." Id. 213.
} 
realitas mempunyai eksplanasi saintifik? ${ }^{18}$ Geire pun menunjukkan masih adanya godaan lain bagi paham naturalisme seperti ini, yaitu untuk membuktikannya secara empiris meski dari perkembangan pengetahuan ilmiah mutakhir muncul sejumlah keraguan apakah kehidupan ini dapat dijelaskan secara keseluruhan sebagai fenomena alam. ${ }^{19}$ Dengan menimbang kesulitan-kesulitan yang menjebak ini, Geire menyarankan supaya naturalisme dipahami secara metodologis sehingga para naturalis bisa menghindarkan diri dari tuntutan untuk membuat justifikasi a priori. ${ }^{20}$

Proyek naturalisme yang menekankan komponen metodologi ini bisa ditemukan sumbernya pada proses pembentukan dan pendasaran ilmu pengetahuan. Ada tiga bidang ilmu yang dalam sorotan Geire menampilkan secara bahu-membahu bekerjanya proses yang natural tersebut, yakni teori evolusi, ilmu kognitif, dan sosiologi ilmu. Teori evolusi dalam kerangka naturalisme menunjukkan fakta penting bahwa manusia mengalami evolusi dengan adanya seleksi alam. Dari pendekatan teori evolusi tampak adanya peran naturalisme dalam perkembangan teori ilmu, yaitu sebagai model proses perubahan pengetahuan ilmiah, sedangkan pendekatan yang lebih longgar melihatnya ada peran tersebut terutama dalam hal variasi idea atau eksperimen, seleksi, dan transmisi atau penyaluran idea serta hasilnya. ${ }^{21}$ Naturalisme yang diaplikasikan menurut teori evolusi menurut pendekatan yang longgar ini menaruh perhatian pula pada isu perkembangan sejarah ilmu.

Naturalisme berdasarkan teori evolusi tersebut masih membutuhkan penjelasan perihal mekanisme seperti apa yang menghasilkan variasi, seleksi, dan transmisi. Seperti yang ditunjukkan Geire, berjalannya mekanisme tersebut dapat ditelusuri berdasarkan pemikiran ilmu kognitif, khususnya yang dewasa ini

\footnotetext{
18 Id. hlm. 214.

${ }^{19}$ Geire mencontohkan pengetahuan ilmiah mutakhir tersebut seperti biologi molekular dan juga studi mengenai kesadaran manusia yang sangat mampu untuk memberikan penjelasanpenjelasan yang non-naturalis.

20 "For any aspect of the world, seek a naturalistic rather than a super-naturalistic (or a priori) explanation." Ronald N. Geire, supra catatan no. 2, pada 214.

21 Id. hlm. 216.
} 
dikembangkan dalam konsep 'sistem kognitif terdistribusi'. Konsep ini menyatakan bahwa proses kognisi terdistribusi ke dalam seluruh sistem sehingga tak terbatas pada lokasi tertentu seperti di dalam komputer atau otak saja. ${ }^{22}$ Dengan begitu, proses ilmiah yang berasal dari kemampuan kognitif tak mesti terlalu dipertentangkan dengan pelbagai penjelasan sosialnya. Sebab, setiap hasil aktivitas kognitif merupakan keluaran (output) dari sistem kognitif yang terdistribusikan pula ke dalam bentuk-bentuk relasi sosial. Lebih lanjut, sosiologi ilmu menekankan ulang adanya aspek sosial dari mekanisme perubahan ilmu, terutama dalam hal transmisi pengetahuan ilmiah. Ilmu kognisi memang mampu menjelaskan soal pengetahuan individu hasil kemampuan kognitifnya. Tetapi yang dinamakan pengetahuan dapat disebut ilmiah sejauh pengetahuan tersebut bersifat publik. ${ }^{23}$ Artinya, pengetahuan tersebut bisa, bahkan harus, diperiksa dan diuji lewat publikasi ilmiah berkala atau pengkajian oleh rekan sejawat (peer review).

Rekonstruksi terhadap proyek naturalisme yang dilakukan ini kiranya memperlihatkan adanya keutamaan-keutamaan dari karakter dan aplikasi proyek tersebut. Sekurang-kurangnya dapat dikatakan bahwa proyek tersebut merupakan proyek raksasa yang berkenaan dengan: (a) gagasan tentang hakikat alam sebagai realitas serta tentang sifat kealaman; (b) cara pandang subyek dalam mengetahui realitas yang berciri (a) dan; (c) langkah-langkah, proses, atau mekanisme menyelidiki sumber pengetahuan berupa (a) yang dipahami menurut (b). Kalau kita amati kontak yang terjadi antar (a), (b), dan (c) tersebut, maka sesungguhnya terdapat pengandaian bahwa naturalisme mengandung komponen ontologi (a), epistemologi (b), dan metodologi (c). Tipologi ketiga komponen ini menjadi petunjuk soal konteks pergulatan masalah naturalisme dalam filsafat ilmu. Duduk perkara perdebatan filsafat hukum sangat dipengaruhi oleh konteks yang demikian. Ekspansi proyek naturalisme ternyata sampai masuk ke ranah filsafat hukum. Berikutnya kita akan mengamati momen persentuhan filsafat

\footnotetext{
22 Id. hlm. 217.
}

23 Id. hlm. 218. 
hukum dengan naturalisme, dimana disposisi serta implikasi dari naturalisme justru mempertajam momen tersebut menjadi gesekan yang menyulut debat metodologi filsafat hukum. Dalam perkara ini, Brian Leiter adalah salah seorang arsitek yang setia memberikan kembali serta memancangkan pilar-pilar naturalisme berupa tiga komponen tadi dalam ranah filsafat hukum.

\section{Naturalisasi Filsafat Hukum}

Seperti yang telah disinggung di bagian awal tulisan ini, doktrin naturalisme yang berpangkal dari pembongkaran Quine terhadap garis batas antara proposisi analitik dan proposisi sintestik berdampak signifikan bagi perdebatan filsafat hukum. Leiter merupakan tokoh yang mencetuskan kontroversi naturalisme ini di dalam perdebatan tersebut. Akibatnya, dua posisi pemikiran besar yang berseteru soal metodologi filsafat hukum - Hart melawan Dworkin - seakan-akan terlampaui sudah. ${ }^{24}$ Selain itu, Leiter juga menegakkan gagasan Quine tentang epistemologi ternaturalisasi sehingga pendasaran konseptual dari pelbagai kerangka teoritis sesungguhnya tidaklah lebih 'filosofis' daripada ilmu pengetahuan 'praktis' yang nomologikal. Leiter mengelaborasi tiga komponen doktrin naturalisme yang telah diperlihatkan sebelumnya menjadi lima varietas naturalisme yang dapat ditemukan dalam diskursus filsafat hukum. Di sini hanya akan ditinjau dua macam variasi naturalisme versi Leiter, yang tanpa kebetulan bersumber dari kritik Quine terhadap pembedaan analitik/sintestik serta gagasan epistemologi ternaturalisasinya.

Namun sebelum itu ada baiknya untuk memahami terlebih dahulu ihwal perdebatan metodologi filsafat hukum, dalam rupa sketsa yang sangat sederhana dengan simplifikasi di sana-sini. Perdebatan ini terkait dengan upaya untuk mengkonseptualisasikan hukum dan telah dimulai dari prakarsa positivisme hukum untuk mengidentifikasi apa yang dinamakan "norma hukum” (legal norm). H. L. A. Hart adalah pemikir yang membangun gagasan "filsafat hukum deskriptif" yang membicarakan konsep norma hukum tersebut. Lantas muncul Ronald

${ }^{24}$ Dennis Patterson, supra catatan no. 6, pada 258. 
Dworkin yang menentang gagasan positivisme hukum Hart tersebut dengan mengajukan keberatan bahwa hukum sebagai suatu konsep pada dasarnya merupakan konsep yang interpretatif. Di situ terdapat nilai dan tujuan yang menjustifikasi ketetapan yang mengatur sehingga filsafat hukum "butuh" bersifat normatif. Duduk perkara perdebatan metodologinya berkisar pada pertanyaan apakah filsafat hukum (deskriptif) itu mungkin tanpa harus memiliki elemen evaluatif (seperti yang diyakini oleh Hart dan para positivis hukum), atau elemen evaluatif itu perlu ada seperti dalam pandangan Dworkin dan John Finnis. ${ }^{25}$

Mengikuti catatan Patterson, putaran debat berikutnya dikejutkan oleh gagasan Leiter yang menyanggah dasar pemikiran debat metodologi tersebut yang masih terikat pada 'analisis konseptual'. Dengan itulah Leiter memanggil Quine dan mendesak pemikiran filsafat hukum tradisional dengan menanggulangi analisis konseptual (yang mengandaikan pembedaan analitik/sintetik) lewat naturalisme. ${ }^{26}$ Maka bisa dibilang bahwa perdebatan filsafat hukum merupakan contoh yang lumayan bagus mengenai soal bagaimana naturalisme menebar kontroversi dalam aplikasinya. Kontroversi yang kalau lebih diperhatikan dengan bijak sebenarnya menciptakan tantangan sekaligus peluang, baik bagi filsafat hukum maupun ilmu-ilmu sosial atau ilmu manusia lainnya. Kita akan tengok kemungkinan seperti ini nanti.

Lima varietas naturalisme dalam filsafat ilmu yang dikembangkan oleh Leiter sebenarnya berakar pada dua varietas kategori besar: naturalisme

25 Id. hlm. 255. Dari materi presentasi Patterson, kita bisa menyimak perkembangan lebih lanjut perdebatan dua pendekatan filsafat analitik dalam filsafat hukum ini. Melalui perwakilan sejumlah orang tokoh pemikirnya, debat tersebut ternyata menjalar menjadi upaya dukungmendukung antar konsep pemikiran. Patterson menggolongkannya ke dalam tiga kelompok. Yang pertama, kelompok deskriptif (positivistis) dengan Hart sebagai tokoh utamanya yang didukung oleh ragam pendekatan 'Positivis Halus' dari Jules Coleman dan 'Positivis Keras' dari Joseph Raz. Yang kedua, kelompok tengah yang diwakilkan terutama oleh Julie Dickson dengan konsepnya 'Filsafat Hukum Evaluatif yang Tak Langsung' (Indirectly Evaluative Jurisprudence). Yang ketiga, kelompok interpretativis dengan Ronald Dworkin dan Stephen Perry sebagai pendukungnya. Lihat: Dennis Patterson, The Methodology Debate in Analytic Jurisprudence: What is At Stake and What Comes Next, camlaw.rutgers.edu/testing/Methodology_ DebateUCL.ppt, (terakhir dakses 8 Januari 2014).

26 Dengan ini maka perdebatan metodologi filsafat hukum ditarik ke dalam fase di mana pembicaraan tentang metafisika dan epistemologi ikut mempengaruhi arah diskusi dan perdebatan. Dennis Patterson, supra catatan no. 6. 
metodologis (atau yang Leiter sebut dengan 'naturalisme-M') dan naturalisme substantif ('naturalisme-S'). 27 Mengikuti rumusan Leiter, naturalisme-M berpandangan bahwa pendasaran filosofis berkesinambungan dengan ilmu pengetahuan entah dalam hal ketergantungan filsafat terhadap hasil aktual metode ilmiah di pelbagai domain atau dalam hal penggunaan langkah-langkah ilmiah tertentu untuk memahami serta menjelaskan sesuatu. Adapun naturalisme$S$ berpandangan bahwa secara ontologis yang ada hanyalah yang bersifat natural atau fisikal saja, atau secara semantis menganggap analisis filosofis yang tepat atas konsep-konsep adalah yang dapat diukur dengan langkah-langkah empiris (berdasarkan psikologi atau fisiologi misalnya).

Dari dua jenis naturalisme inilah kemudian berkembang lima varietas naturalisme dalam filsafat hukum. ${ }^{28}$ Kita hanya akan menyinggung Naturalisme Penggantian secara khusus karena idea-ideanya berhutang banyak pada pemikiran Quine yang, seperti telah dicoba dibeberkan, punya andil dalam proyek naturalisme. Kendati naturalisme dan filsafat hukum ditinjau menurut korelasi ini 'belaka', pelbagai konsekuensi filosofis yang muncul darinya terhadap tonggak pemikiran filsafat ilmu tidak bisa dianggap enteng. Hal itu akan kentara saat kita menyaksikan implikasi metodologis bagi ilmu pengetahuan. Pembedahan ide Naturalisme Penggantian ini akan berpatokan pada tiga pertanyaan petunjuk: (1) gagasan dan konsep apa yang ditanggapi oleh Naturalisme Penggantian?; (2) apa posisi argumentasi Naturalisme Penggantian?; (3) di titik mana dampak argumentasi tersebut dalam diskursus filsafat hukum? Ada dua jenis rute

27 Brian Leiter, Naturalism in Legal Philosophy, http://plato.stanford.edu/archives/fall2012/ entries/lawphil-naturalism/ (terakhir diakses 3 Januari 2014).

${ }^{28}$ Seperti yang ditampilkan oleh Leiter, terdapat varietas 'Naturalisme Penggantian' (Replacement Naturalism) yang diolah lebih lanjut oleh gerakan Realisme Hukum Amerika contohnya.Lalu varietas 'Naturalisme Normatif' (Normative Naturalism) yang tampak pada konsep epistemologi Alvin Goldman.Yang menarik, pemikiran Hart bersama aliran Realisme Skandinavian bisa dikatakan termasuk ke dalam varietas 'Naturalisme Substantif Awal' di samping varietas naturalisme substantif yang berkembang kemudian dengan berpadu bersama realisme moral dan teori hukum alam. Ekspos lebih mendalam tentang semuanya ini bisa dibaca: Id. 
argumentasi Naturalisme Penggantian yang perlu diteliti dan kedua-duanya bersumber dari pemikiran Quine. ${ }^{29}$

Rute yang pertama beranjak dari sanggahan Quine terhadap pembedaan analitik/sintesik seperti beberapa kali telah disebut sebelum ini. Semangat naturalisme Quine menolak keberlakuan pembedaan yang kuat dipengaruhi oleh garis pemikiran positivisme logis tersebut karena bagi Quine semua bentuk pernyataan, pada dasarnya, dapat dimengerti berdasarkan pengalaman. Jadi yang ada hanyalah fakta sosial-historis yang terus bergulir dan membentuk pernyataan-pernyataan yang kita buat. Pendeknya, tiada lagi domain kebenaran analitik. Dengan ini, analisis konseptual yang dominan meliputi filsafat pun kehilangan tajinya sehingga lebih baik membangun teori a posteriori seperti yang disajikan oleh ilmu-ilmu empiris daripada bicara filsafat yang serba a priori. Dalam rute argumentasi Naturalisme Penggantian ini, filsafat cukup menjadi abstraksi dari ilmu empiris yang sudah 'lebih dahulu' berhasil menjelaskan hubungan-hubungan kausal dari pelbagai masalah sosial. Dampak argumentasi ini dalam diskursus filsafat hukum bisa ditemukan pada pendekatan ilmu-ilmu sosial terhadap proses pembentukan keputusan yudisial. Apa yang dinilai dari suatu keputusan yudisial adalah kontribusi kausal relatif di antara faktor hukum dan non-hukum. Penjelasan non-hukum yang didekati dari perspektif ilmu sosial ini berguna dengan baik untuk mengungkapkan pelbagai faktor yang kerap tersembunyi dan sulit dideteksi seperti faktor psiko-sosial, pendirian ideologi, serta keterjalinan fenomena hukum dengan perilaku sosial-politik yang ada.

Rute lainnya merupakan bagian dari program pengguncangan fondasionalisme. Gagasan fondasionalis Cartesian, serta yang diolah lebih lanjut oleh Carnap, sangat gigih untuk memberikan landasan bukti bagi sebuah teori. Epistemologi menurut fondasionalisme adalah urusan hubungan justifikasi antara teori dan bukti, nalar dengan keyakinan, sejarah kausal dengan konten semantis atau intensionalitasnya. Selaras dengan rute sebelumnya, argumentasi

\footnotetext{
${ }^{29}$ Uraian yang menyangkut hal ini sepenuhnya mengikuti apa yang disampaikan Leiter dalam: Id.
} 
Naturalisme Penggantian pada rute ini melihat adanya kegagalan epistemologi fondasionalis untuk mempertahankan relasi teori-bukti sehingga lebih baik epistemologi dinaturalisasi saja dan berpaling ke ilmu-ilmu empiris. Penyebabnya, seperti kata Quine, fondasionalisme secara semantis gagal memaknai keseluruhan kerangka teoritis yang ada alias berteori dengan modal adanya kontak teori dengan bukti saja. Secara epistemis pun fondasionalisme dinilai gagal karena seolah memaksakan diri atas nama konsistensi untuk mencocok-cocokan satu teori saja dengan bukti. Padahal selalu ada lebih dari satu teori yang konsisten dengan suatu bukti. Ketika diterapkan pada diskursus filsafat hukum, Naturalisme Penggantian dari rute ini berdampak paling nyata pada gerakan "antifondasionalis" Realisme Hukum Amerika. Mereka dengan tegas menolak teori ajudikasi yang memandang adanya determinasi antara penalaran hukum (legal reasoning) dan keputusan hukum (judicial decision). Di sini penalaran hukum analog dengan teori sedangkan keputusan hukum dengan bukti. Penalaran hukum pun tidak punya status istimewa dalam menjustifikasi keputusan hukum. Alhasil, filsafat hukum ternaturalisasi menjadi tak adanya bedanya dengan kajian psikologi, ekonomi, sosiologi, dan lain-lain.

Tampak bahwa kedua rute Naturalisme Penggantian ini berujung pada kesamaan kondisi yang mengemukakan ketiadaan determinasi dan penghapusan dasar normatif sebuah teori. Siasat yang dijalankan lewat Naturalisme Penggantian ini adalah menggantikan teori konseptual dan justifikasi yang tradisional dengan teori empiris dan deskriptif. Debat metodologi filsafat hukum tentu memasuki level yang berbeda tatkala harus berhadapan pelbagai argumentasi dan pendirian Naturalisme Penggantian ini. Mungkin yang paling merepotkan ketika kita ingin menampik keutamaan Naturalisme Penggantian tersebut adalah intensitas kemungkinannya dalam menggapai kebenaran. Hal ini tampak jelas apabila kita mempertimbangkan petunjuk (4) di samping tiga lainnya tadi, yaitu keberatan-keberatan terhadap keberlakuan Naturalisme Penggantian pada wilayah filsafat hukum. Contohnya saja, mengambil dari Leiter, keberatan 
yang menyatakan bahwa konsep Realisme Hukum yang analog dengan kritik fondasionalisme Quine tetaplah terikat pada determinasi rasional hukum. Keberhasilan teoritis Realisme Hukum yang didasarkan pada Naturalisme Penggantian pun sangat diragukan karena tiadanya landasan normatif. ${ }^{30}$ Namun keberatan ini luput mengindahkan dimensi di samping rasionalitas itu berupa proses evolusi penyaluran pengetahuan, mekanisme distribusi kapasitas kognitif, dan publikasi ilmu pengetahuan seperti yang ditunjukkan oleh teori evolusi, ilmu kognitif, dan sosiologi ilmu pengetahuan. Lalu klaim tentang keberhasilan teoritis menurut naturalisme tetap berlaku seturut dinamika perkembangan ilmu, di mana teori yang sukses dengan standar penjelasnya tentu akan lebih pantas dirujuk serta diadopsi daripada teori yang tidak sukses. ${ }^{31}$ Jawaban doktrin naturalisme terhadap keberatan ini berada pada jalur epistemologi ternaturalisasi.

Keberatan di atas hanya merupakan salah satu contoh dari rute argumentasi yang anti-fondasionalis. Dari rute argumentasi yang menghapus pembedaan analitik/sintetik muncul pula keberatan berupa skeptisisme (dari kubu analis konseptual) terhadap penjelasan ilmu sosial (empiris) dalam mengkonsepsikan hukum karena menganggap penjelasan itu tidak memiliki topangan kepada intuisi. ${ }^{32}$ Jawaban untuk keberatan ini datang dari naturalisme metodologis yang mengambil alih wilayah intuisi untuk digantikan dengan ilmuilmu bonafide yang mampu menghasilkan teori yang benar dan yang menjelaskan. ${ }^{33}$ Leiter sendiri menawarkan jalan keluar lain untuk

\footnotetext{
${ }^{30}$ Id.

${ }^{31}$ Alexander Bird, supra catatan no. 11, pada 28.

32 Repotnya lagi, pendekatan ilmu sosial ternyata memang lemah secara epistemis saat harus menjelaskan kausalitas konsep hukum dengan aspek-aspek sosial-politis.Sebab, model penjelasan yang ada masih mengandaikan serta mengandalkan konsep hukum yang positivis. Brian Leiter, Naturalizing Jurisprudence: Three Approaches, http://papers.ssrn.com/ sol3/papers.cfm?abstract_id=1288643 (terakhir diakses 3 Januari 2014).

33 Hal ini sangat menonjol dalam perkataan Robert Cummins yang dihidupi oleh semangat Quinean dan disitir Leiter berikut ini: "Kita bisa menyerah atas intuisi tentang hakikat ruang dan waktu dan lantas bertanya makhluk jenis apakah ruang dan waktu itu apabila teori fisika yang ada sekarang ada benarnya dan mampu menjelaskan. Kita bisa menyerah atas intuisi tentang konten
} 
mempertahankan naturalisasi filsafat hukum lewat filsafat eksperimental. Siasat naturalisasi pun digeser; dari yang semula mempertanyakan hakikat hukum secara natural di ranah konseptual, menjadi proses menteoritisasi praktik ajudikasi secara natural dengan memprakarsakan kembali ajaran realisme hukum.

\section{Tantangan sekaligus Peluang}

Pengembangan varietas naturalisme-M dan naturalisme-S dalam filsafat hukum rupanya mengimpor doktrin naturalisme yang terjabarkan menurut tipologi komponen ontologis, epistemologis, dan metodologis. Dengan mengambil contoh kasus perdebatan filsafat hukum, dan lebih spesifik lagi salah satu contoh varietas naturalisme dalam filsafat hukum yakni Naturalisme Penggantian, didapati bahwa siasat naturalisme adalah untuk menggantikan posisi filsafat ilmu tradisional dalam wujud analisis konseptual yang bersandar pada intuisi dan fondasionalisme epistemologis yang menekankan deduksi atas rasionalitas. Belajar dari tanggapan Naturalisme Penggantian terhadap keberatan-keberatan yang ada di dalam dua rute argumentasinya, doktrin naturalisme menyajikan tantangan sekaligus peluang yang coraknya kental terasa lewat epistemologi ternaturalisasi dan naturalisme metodologis.

\section{Epistemologi Ternaturalisasi}

Idea tentang epistemologi ternaturalisasi sebenarnya paling gamblang diutarakan di dalam karyanya Quine. ${ }^{34}$ Tetapi dengan melihat rancangan proyek naturalisme yang berimbas pada metafisika, epistemologi, filsafat ilmu, serta pemikiran di bidang filsafat hukum dan ilmu sosial, ide epistemologi ternaturalisasi kiranya bisa kita tinjau berdasarkan karakterisasi yang diungkapkan oleh Bird. Dengan karakter eksternalisnya, epistemologi ternaturalisasi meyakini bahwa kapasitas penalaran seseorang tidaklah dimulai

representasional kita dan lantas bertanya representasi-representasi mental seperti apa apabila teori kognitif yang ada sekarang ada benarnya serta mampu menjelaskan."Id. 4-5.

34 Karya yang dimaksud adalah: W. V. Quine, "Epistemology Naturalized" dalam Ontological Relativity and Other Essays 69-90 (Columbia University Press, New York, 1969). 
dari refleksi diri yang ditambah dengan pengalaman sensoris subjektif a la pemikiran Cartesian, melainkan tumbuh dan berevolusi di dalam kondisi lingkungan tertentu. ${ }^{35}$ Gagasan ini membuka kesempatan bagi pluralisme metodologi karena menganggap proses pembentukan kapasitas pengetahuan sebagai proses yang a posteriori.

Epistemologi ternaturalisasi juga mendukung kecukupan reliabilitas metode yang diyakini dalam memahami objek yang tak dapat diobservasi, seperti yang ditempuh oleh realisme ilmiah. Tendensi partikularis 'berganda' yang dicontohkan melalui 'Kesimpulan untuk Eksplanasi Terbaik' menampilkan dimensi pengorganisasian sosial ilmu, di mana terdapat optimisme bahwa justifikasi atas pengetahuan itu mungkin, yakni dengan memakai hasil investigasi empiris, tanpa harus menunggalkan standar penjelas yang paling baik. Kalau program-program epistemologi ternaturalisasi ini dirasa masih belum menjanjikan karena masih hipotetis belaka, Bird menyodorkan bukti sebagaimana yang telah disuplai oleh Kuhn dengan menunjukkan bahwa teori atau praktik ilmiah yang sukses terbentuk dari proses evaluasi yang dilakukan para ilmuwan terhadap pelbagai standar penjelas. ${ }^{36}$

\section{Naturalisme Metodologis}

Betapa memprovokasinya program epistemologi ternaturalisasi tampak lebih jelas manakala naturalisme diejawantahkan secara metodologis sebagaimana yang diformulasikan oleh Geire. Mengambil inspirasi dari konsep evolusi Darwin, Geire berpendapat bahwa dengan memusatkan diri pada komponen metodologi, naturalisme akan menjangkau apa yang tampak pada gejala-gejala alam. Normativitas bukannya tidak mungkin berdasarkan pandangan seperti ini, asal tidak begitu saja menyamakannya dengan materialisme. Namun, apa yang normatif tetap dimengerti sebagai bagian dari proses natural sehingga bukanlah ketetapan normatif sebagai justifikasi melainkan genealogi terhadap

\footnotetext{
35 Alexander Bird, supra catatan no. 11, pada 26.

${ }^{36}$ Id. hlm. 28.
} 
justifikasi yang menjadi patokan bagi pengertian normativitas. Untuk meneguhkan eksistensi naturalisme metodologis, Leiter menggambarkan pencapaian kinerja cabang-cabang ilmu pengetahuan yang sukses dengan "prediksi dan kontrol" dalam tren waktu lima puluh tahun belakangan. ${ }^{37}$ Begitu pun halnya dengan Geire yang menghitung tingkat kesuksesan dari komitmen terhadap naturalisme metodologis, yaitu selama 300 tahun belakangan. ${ }^{38}$

Dari pendekatan naturalisme metodologis Leiter, tantangan sekaligus peluang bagi filsafat hukum umumnya dan teori ajudikasi khususnya lugas ${ }^{39}$ :

“... daripada hanya berpura-pura bahwa hukum menjustifikasi satu dan hanya satu keputusan dalam suatu penyelesaian masalah hukum yang penting dan menyita perhatian (yakni di mahkamah pengadilan tertinggi), alangkah lebih berfaedah untuk membangun penjelasan yang masuk akal sesuai pembuktian empiris, yakni pola-pola keputusan pengadilan menurut tipe situasi yang beragam."

Konsekuensi teoritis dari kecenderungan metodologis seperti ini adalah semacam favoritisme terhadap pandangan metodologis tertentu. Artinya, ilmu pengetahuan yang menganut naturalisme metodologis ini memahami dunia menurut proses dan gejala alam alias merampatkan hakikat manusia, kebudayaan, serta kehidupan sosial secara empiris.

Sesungguhnya terdapat pendirian metodologi yang heterogen, bahkan saling bersinggungan, di dalam kerangka jenis-jenis ilmu pengetahuan. Keadaan multi-metodologi agaknya sulit dihindari manakala metodologi jenis-jenis ilmu pengetahuan ini (masih tetap) diperdebatkan. Kristalisasi persoalan metodologis ini adalah kontroversi antara "Penjelasan" dan "Pemahaman" (Erklären-Verstehen) yang mencuat berkat pembedaan ilmu-ilmu alam dan ilmu-ilmu manusia

\footnotetext{
37 Brian Leiter, supra catatan no. 33, pada 1.

38 Ronald N. Geire, supra catatan no. 2.

39 "... it suggests that rather than pretending that the law justifies one and only one decision in the kinds of legal disputes that attract the most attention (e.g.., decisions of the U..S.. Supreme Court), we would be better served-as theorists and as lawyers-in contructing explanations that make sense of the empirical evidence, namely, the patterns of decisions by courts across differing situation-types." Brian Leiter, supra catatan no. 33, pada 12.
} 
(Naturwissenschaften-Geisteswissenschaften). ${ }^{40}$ Tentu dibutuhkan tempat tersendiri untuk membahas masalah perdebatan metodologi ilmu-ilmu ini.

\section{Penutup}

Paparan di atas telah berusaha mengungkapkan bagaimana siasat-siasat naturalisme bekerja dan berimplikasi bagi pokok-pokok pemikiran filsafat ilmu. Proyek naturalisme bisa ditemukan dari pergulatan filsafat ilmu dengan metafisika dan berlanjut dalam perjumpaan filsafat dengan epistemologi. Dari yang disebut terakhir ini epistemologi ternaturalisasi dikedepankan berdasarkan keutamaan ilmiahnya untuk mencapai, atau paling tidak, berkorelasi, dengan kebenaran. Berdasarkan komponen metodologinya, siasat naturalisme pun hendak direkonsiliasikan dengan ilmu pengetahuan. Lebih jauh lagi, naturalisme metodologis yang bervarietas Naturalisme Penggantian bermaksud menyudahi perdebatan di wilayah filsafat hukum.

Implikasi dari argumentasi-argumentasi naturalisme yang mempengaruhi perdebatan filsafat hukum terletak pada masalah metodologi keilmuan hukum. Hal ini terlihat dari doktrin epistemologi ternaturalisasi dan naturalisme metodologis. Dari sudut pandang naturalisme, disiplin keilmuan hukum tidak cukup dan bahkan tidak perlu terbatas pada pendirian metodologis yang dogmatis dalam mempelajari gejala hukum. Akan tetapi secara paradoksal, dua doktrin naturalisme tersebut membuat metodologi disiplin keilmuan hukum tersebut bercorak sangat empiris dan realis. Artinya, kewibawaan filsafat hukum sebagai penyelidikan filosofis atas hakikat atau kodrat hukum menjadi tergoyahkan.

Naturalisme memang datang seperti pencuri, maka berbahagialah para ilmuwan hukum yang memperhatikan kontribusi filsafat ilmu ini.

\footnotetext{
40 Ign. Bambang Sugiharto, Paradigma Ilmu-ilmu Manusia: Antara Kant dan Ricoeur, 10 Majalah Melintas. 1, 6 (1987).
} 


\section{Daftar Pustaka}

\section{Buku:}

Bird, Alexander. 2011. "Philosophy of Science and Epistemology" dalam The Continuum Companion to the Philosophy of Science. Steven French and Juha Saatsi (eds.). London and New York: Continuum.

Callender, Craig. 2011. "Philosophy of Science and Metaphysics" dalam The Continuum Companion to the Philosophy of Science. Eds. Steven French and Juha Saatsi (eds.). London and New York: Continuum.

Geire, Ronald N. 2008. "Naturalism" dalam The Routledge Companion to Philosophy of Science. Stathis Psillos and Martin Curd (eds.). London and New York: Routledge.

Hanna, Robert. 2008. "Kant in the Twentieth Century" dalam The Routledge Companion to Twentieth Century Philosophy. Dermot Moran (ed.). London and New York: Routledge.

Ign. Bambang Sugiharto. 1987. "Paradigma Ilmu-ilmu Manusia: Antara Kant dan Ricoeur". Majalah Melintas. No. 10, April. Bandung: Fakultas Filsafat Universitas Katolik Parahyangan.

\section{Situs internet:}

Leiter, Brian. 2008. "Naturalizing Jurisprudence: Three Approaches". The Social Science Research Network Electronic Paper Collection. http://papers.ssrn.com/sol3/papers.cfm?abstract_id=1288643. Diakses pada 3 Januari 2014.

Leiter, Brian. 2012. "Naturalism in Legal Philosophy". The Stanford Encyclopedia of Philosophy (Fall 2012 Edition). Edward N. Zalta (ed.). URL = http://plato.stanford.edu/archives/fall2012/entries/lawphil- naturalism/ Diakses pada 3 Januari 2014.

Marmor, Andrei. 2011. "The Nature of Law". The Stanford Encyclopedia of Philosophy (Winter 2011 Edition), Edward N. Zalta (ed.), URL = http://plato.stanford.edu/archives/win2011/entries/lawphil-nature/. Diakses pada 19 Maret 2015.

Patterson, Dennis. 2005. "Notes on the Methodology Debate in Contemporary Jurisprudence: Why Sociologist Might Be Interested". The Social Science Research NGeireetwork Electronic Paper Collection. http://papers.ssrn.com/sol3/papers.cfm?abstract_id=848984. Diakses pada 3 Januari 2014.

Patterson, Dennis. 2008. The Methodology Debate in Analytic Jurisprudence: What is At Stake and What Comes Next, camlaw.rutgers.edu/testing/Methodology_DebateUCL.ppt,. Diakses pada 8 Januari 2014. 